\title{
PENGARUH MODEL PEMBELAJARAN CONCEPTUAL UNDERSTANDING PROCEDURES (CUPS) BERBANTUAN LKPD TERHADAP KEMAMPUAN PEMECAHAN MASALAH FISIKA
}

\author{
Ibrahim, Kosim, Gunawan \\ Program Studi Pendidikan Fisika \\ FKIP, Universitas Mataram \\ Jalan Majapahit No. 62, Mataram \\ E-Mail: Baimphysics@gmail.com
}

\begin{abstract}
This study aims to determine the effect of learning model Conceptual Understanding Procedures LKPD assisted on the ability of solving physics problems of high school students. This research is a quasi experimental research using untreated control group design with pretest and posttest. The population is all students of class XI IPA SMAN 4 Mataram. While the sampling using purposive sampling technique consisting of students class XI IPA 4 as experimental class and students of class XI IPA 1 as a control class. The problem solving capability data is obtained through a written test in the form of a description item. The result of hypothesis test analysis shows that there is influence of learning model of LKPD-assisted Conceptual Understanding Procedures toward the ability of problem solving physics.
\end{abstract}

Keywords: Conceptual Understanding Procedures (CUPs), LKPD, physics problem solving skills

\section{PENDAHULUAN}

Ilmu Pengetahuan Alam (IPA) atau Sains merupakan pengetahuan yang diperoleh melalui pembelajaran, penguasaan, pengetahuan, proses penemuan, konsep-konsep, dan fakta-fakta yang melingkupi kebenaran dari hukum-hukum alam yang terjadi dan dapat dibuktikan melalui metode ilmiah. Trianto (2010) berpendapat bahwa sains diambil dari bahasa latin scientia yang artinya pengetahuan. Dalam sains setiap teori selalu didasarkan pada langkah eksperimen yang dapat dipertanggung jawabkan secara akal sehat. Pembelajaran sains merupakan pembelajaran yang berkaitan dengan cara mencari tahu tentang alam secara sistematis, sehingga sains bukan hanya penguasaan kumpulan pengetahuan yang berupa fakta-fakta, konsep-konsep, atau prinsip-prinsip saja tetapi juga merupakan suatu proses penemuan (Sinambela \& Turnip, 2015). Secara umum IPA meliputi tiga bidang ilmu dasar, yaitu Fisika, Biologi, dan Kimia.

Fisika merupakan bagian dari sains yang memfokuskan kajiannya pada materi, energi, dan hubungan antara keduanya (Gunawan et al, 2015). Fisika juga merupakan salah-satu mata pelajaran Ilmu Pengetahuan Alam yang berkaitan dengan cara mencari tahu tentang gejala, peristiwa ataupun fenomena alam secara sistematis (Fransiska \& Markos, 2016). Fisika merupakan ilmu yang lahir dan berkembang melewati langkah-langkah observasi, perumusan masalah, penyusunan hipotesis, pengujian hipotesis melalui eksperimen, penarikan kesimpulan, serta penemuan teori dan konsep. Bermula dari adanya rasa ingin tahu yang besar mengantarkan para ilmuan menghasilkan suatu kumpulan pengetahuan yang disusun secara sistematis yang kemudian saat ini diajarkan kembali dalam pembelajaran fisika.

Pembelajaran fisika adalah pembelajaran yang tidak mengabaikan hakikat fisika sebagai sains (Hariawan et al, 2014). Pembelajaran fisika yang sering dijumpai di sekolah ialah pembelajaran fisika dengan menggunakan pembelajaran langsung dan metode ceramah. Pembelajaran dengan metode ceramah merupakan sebuah bentuk interaksi melalui penerangan dan penuturan lisan dari guru kepeda peserta didik (Sagala, 2013). Proses pembelajaran yang berlangsung masih didominasi oleh pembelajaran yang kurang melibatkan peran aktif peserta didik. Pembelajaran yang digunakan masih berpusat pada guru dan sebatas transfer informasi, terlebih pada materi berupa teori dan persamaan matematis. Pembelajaran yang hanya mentransfer informasi dapat mengakibatkan peserta didik menjadi pasif dan kurang memahami konsep sehingga mempengaruhi rendahnya kemampuan peserta didik. Menurut Sugiana et al (2016), siswa selalu memiliki gaya pembelajaran yang berbedabeda serta penilaian berbeda mengenai pembelajaran yang sedang berlangsung. 
Upaya perancangan pembelajaran inovatif dengan menggunakan strategi yang efektif terhadap pemahaman konsep dan kemampuan pemecahan masalah siswa perlu dilakukan (Dwi et $a l, 2013)$. Pengorganisasian proses pembelajaran sangat penting dalam meningkatkan kemampuan pemecahan masalah peserta didik. Proses pembelajaran yang baik tidak hanya memperhatikan penyampaian konsep, tetapi juga memperhatikan proses kemampuan pemecahan masalah oleh peserta didik. Pengorganisasian proses pembelajaran dapat menggunakan model pembelajaran yang baik dan melibatkan peran aktif peserta didik. Salah-satu model pembelajaran yang dapat digunakan untuk meningkatkan kemampuan pemecahan masalah adalah model pembelajaran Conceptual Understanding Procedures (CUPs).

CUPs dikembangkan dengan

menggunakan pendekatan konstruktivisme, yaitu model pembelajaran yang didasarkan pada keyakinan bahwa peserta didik dapat membangun pemahaman konsep mereka sendiri dengan memperluas atau memodifikasi pengalaman yang dimiliki peserta didik. Model pembelajaran CUPs adalah suatu model pembelajaran dimana pada peserta didik ditanamkan bagaimana membuat kesimpulan atas materi yang dipelajari. Menurut Prastiwi et al (2014) menyatakan bahwa CUPs merupakan model pembelajaran yang dirancang untuk membantu perkembangan pemahaman siswa dalam menemukan konsep yang sulit. Model pembelajaran CUPs menegaskan pentingnya peran aktif individu dan tanggung jawab atas pencapaian pemahaman bersama oleh kelompok (Hidayati \& Sinulingga, 2015).

Pada penerapan model pembelajaran CUPs, peserta didik dibagi dalam kelompok-kelompok kecil. Setiap kelompok beranggotakan tiga peserta didik (triplet), namun pembagian kelompok dapat menyesuaikan jumlah peserta didik dalam kelas. Pembagian kelompok dilakukan secara heterogen, artinya setiap kelompok harus beranggotakan minimal satu peserta didik putra, kemampuan kognitif peserta didik dalam satu kelompok juga harus konvergen (rendah-sedang-tinggi). Saregar et al (2016) menyatakan bahwa model CUPs dibangun atas tiga fase, yaitu (1) fase individu; (2) fase kerja kelompok; dan (3) fase presentase. Tiga fase utama pembelajaran CUPs di atas, digunakan peneliti sebagai skenario untuk melaksanakan proses pembelajaran pada kegiatan inti. Dan untuk kegiatan awal dan akhir sama halnya dengan langkah-langkah pada model-model pembelajaran lainnya. Oleh karena itu dalam langkah-langkah pembelajaran CUPs diharapkan dapat membimbing peserta didik memahami konsep baru, sehingga kemampuan pemecahan masalah peserta didik meningkat.

Penelitian terkait dengan model pembelajaran CUPs antara lain dilakukan oleh Ismawati et al (2014) menyatakan bahwa model pembelajaran Conceptual Understanding Procedures terbukti lebih efektif untuk meningkatkan pemahaman konsep dan curiosity siswa pada pelajaran fisika. Selain itu, Hikmah et al (2015) menyimpulkan bahwa penerapan model pembelajaran Conceptual Understanding Procedures dapat meningkatkan aktivitas dan hasil belajar matematika siswa kelas $\mathrm{X}$ SMAN 7 Mataram tahun ajaran 2014/2015. Penelitian Anggreni et al (2013) menyatakan bahwa model pembelajaran Conceptual Understanding Procedures berpengaruh terhadap hasil belajar matematika pada siswa kelas V SD Gugus VII Komping Sujana, Denpasar Barat tahun ajaran 2012/2013.

Selain pemilihan model pembelajaran yang tepat, peran media pembelajaran juga secara teori berpengaruh terhadap kemampuan pemecahan masalah fisika peserta didik. Trianto (2010) menjabarkan istilah media pembelajaran adalah sebagai penyampai medium sebagai pesan (the carriers of massages) dari beberapa sumber saluran ke penerima pesan (the receiver of the massages). Media pembelajaran dapat membangkitkan motivasi peserta didik untuk belajar dan sangat membantu keefektifan proses pembelajaran (Suranti et al, 2016). Salah satu alternatif media yang dapat digunakan adalah media lembar kerja peserta didik (LKPD). LKPD merupakan sebutan baru yang awalnya dikenal dengan LKS. Perubahan nama LKS menjadi LKPD disebabkan oleh perubahan paradigma atau pandangan pendidikan tentang guru dan siswa.

LKS yaitu materi ajar yang sudah dikemas sedemikian rupa, sehingga siswa diharapkan dapat mempelajari materi ajar tersebut secara mandiri (Damayanti, 2013). Hal ini didukung oleh Lubis \& Lestari (2017) yang menyatakan bahwa LKS merupakan media pembelajaran yang dapat 
dikembangkan oleh guru, yang berperan sebagai fasilitator dalam kegiatan pembelajaran. LKS digunakan sebagai acauan atau memandu pelaksanaan kegiatan pembelajaran dan juga sebagai alat pembelajaran (Sukmawati \& Lestari, 2017).

Kelebihan dari penggunaan LKPD dalam pembelajaran akan meningkatkan efisiensi, motivasi, serta memfasilitasi belajar aktif eksperimental, konsisten dengan belajar yang berpusat pada peserta didik dan membantu untuk belajar lebih baik. Lembar kegiatan siswa dapat berupa panduan untuk latihan pengembangan aspek kognitif maupun panduan untuk mengembangkan semua aspek pembelajaran dalam bentuk panduan eksperimen atau demonstrasi (Sahidu, 2013). Hal ini sejalan dengan pendapat Hermansyah et al (2015) yang menyatakan bahwa praktek penggunaan LKPD atau yang sering diebut LKS merupakan kumpulan materi, contoh soal, dan latihan soal.

Menurut Prastowo (2015) ada empat poin tujuan dari penyusunan LKS, yaitu: (1) menyajikan bahan ajar yang memudahkan peserta didik untuk berinteraksi dengan materi yang diberikan; (2) menyajikan tugas-tugas yang meningkatkan penguasaan peserta didik terhadap materi yang diberikan; (3) melatih kemandirian belajar peserta didik; dan (4) memudahkan pendidik dalam memberikan tugas kepada peserta didik.

Peneliti berpendapat bahwa lembar kerja peserta didik adalah suatu bahan ajar cetak berupa lembaran-lembaran berisi permasalahan berkaitan dengan materi optik yang harus dikerjakan oleh peserta didik untuk melakukan kegiatan agar peserta didik memperoleh pengetahuan dan keterampilan yang perlu dikuasai secara mandiri. LKPD memuat identitas, petunjuk, informasi penting, langkah-langkah untuk menyelesaikan suatu tugas, dan permasalahan yang harus diselesaikan. Suatu tugas yang diperintahkan dalam lembar kegiatan harus jelas tujuan yang akan dicapainya.

Penggunaan LKPD sebagai alat bantu dalam melaksanakan proses pembelajaran diharapkan mampu meningkatkan kemampuan pemecahan masalah fisika. Setiap individu memiliki kemampuan yang berbeda-beda untuk menyelesaikan/ memecahkan masalah dalam kehidupan sehari-hari. Menurut Husna \& Fatimah
(2013) menyatakan bahwa masalah adalah suatu persoalan/pertanyaan membutuhkan penyelesaian/jawaban yang tidak bisa diperoleh secara langsung. Pemecahan masalah dapat diartikan sebagai proses menghilangkan masalah yang ada, dimana didalamnya terdapat hubungan atau konsep-konsep yang diperolehnya dalam memecahkan masalah (Sambada, 2012). Hal ini didukung oleh Santrock (2011) yang menyatakan bahwa pemecahan masalah adalah mencari cara yang tepat untuk mencapai suatu tujuan.

Belajar pemecahan masalah pada hakikatnya adalah belajar berpikir (learning to think) atau belajar bernalar (learning to reason), yaitu berpikir atau bernalar mengaplikasikan pengetahuanpengetahuan yang telah diperoleh sebelumnya untuk memecahkan masalah-masalah baru yang belum pernah dijumpai (Gunawan et al, 2015). Kemampuan pemecahan masalah adalah kemampuan kognitif tingkat tinggi, tahap berpikir pemecahan masalah setelah tahap evaluasi yang menjadi bagian dari tahapan kognitif Bloom (Venisari et al, 2015). Sedangkan menurut Rahmat et al (2014) Kemampuan pemecahan masalah memerlukan suatu keterampilan dan kemampuan khusus yang dimiliki masing-masing peserta didik, yang mungkin akan berbeda antar peserta didik dalam menyelesaikan suatu masalah. Siswa perlu memahami dan menggabungkan konsep yang satu dengan yang lainnya dalam memecahkan masalah fisika (Hastuti et al, 2016). Menurut Sulistyowati, et al (2012), salah-satu strategi memecahkan masalah yang biasa digunakan adalah pemecahan masalah sistematis (systematic approcach to problem solving). Kemampuan memecahkan masalah sangat dibutuhkan oleh peserta didik. Memecahkan suatu masalah merupakan suatu aktivitas dasar manusia karena dalam menjalani kehidupan manusia pasti berhadapan dengan masalah (Hertiavi et al, 2010).

Oleh karena itu, dengan menggabungkan suatu model CUPs dengan bantuan LKPD memungkinkan proses pembelajaran lebih efektif. Masalah-masalah fisika dapat disajikan melalui lembar kerja peserta didik sehingga peserta didik akan terlibat didalamnya, proses pembelajaran lebih menarik, tujuan pembelajaran dapat tersampaikan dengan baik, dan kemampuan peserta didik dalam memecahkan masalah dapat dilakukan. 
Belum adanya penggunaan model pembelajaran CUPs yang digabungkan dengan LKPD, serta dari beberapa penelitian terkait masih pada materi yang lain, dan juga model pembelajaran CUPs cenderung mengukur hasil belajar dan pemahaman konsep peserta didik, maka peneliti merasa tertarik untuk melakukan penelitian pada bidang studi fisika dengan materi optik untuk mengukur kemampuan pemecahan masalah peserta didik.

Penggunaan model pembelajaran Conceptual Understanding Procedures (CUPs) yang digabungkan dengan LKPD sangat cocok digunakan di SMAN 4 Mataram. Hal ini didukung dari hasil observasi di SMA Negeri 4 Mataram, yang menunjukan bahwa pembelajaran di kelas masih monoton dan berpusat pada guru. Peneliti berharap penggunaan model pembelajaran CUPs berbantuan LKPD di SMAN 4 Mataram mampu meningkatkan kemampuan pemecahan masalah peserta didik pada pembelajaran fisika di tingkat sekolah menengah atas.

\section{METODE PENELITIAN}

Penelitian kuasi eksperimen ini menggunakan desain non-equivalent control group design with pre-test-and post-test. Suatu penelitian memiliki beberapa variabel penelitian sehingga pembaca mengetahui alur dari sebuah eksperimen. Penelitian ini melibatkan variabel bebas yaitu model pembelajaran Conceptual Understanding Procedures berbantuan LKPD, variabel terikat yaitu kemampuan pemecahan masalah fisika, dan variabel kontrol yaitu waktu, guru yang mengajar dan materi ajar.

Penelitian ini dilakukan di SMA Negeri 4 Mataram. Populasi penelitian adalah 4 kelas berisi 148 peserta didik. Sampel penelitian adalah 73 peserta didik yang dibagi dalam dua kelas yaitu 36 peserta didik sebagai kelas kontrol dan 37 peserta didik sebagai keals eksperimen. Pemilihan sampel ditentukan dengan purposive sampling. Purposive sampling adalah teknik penentuan sampel dengan pertimbangan tertentu (Sugiyono, 2012).

Instrumen yang digunakan adalah tes kemampuan pemecahan masalah. Teknik pengumpulan data berupa tes tertulis berbentuk soal uraian. Tes kemampuan pemecahan masalah berjumlah 7 soal. Indikator yang digunakan dalam tes kemampuan pemecahan masalah ini adalah (1)
Pemahaman (understanding) yaitu kemampuan memahami ide atau gagasan dalam setiap soal; (2) Pemilihan (selecting) yaitu kemampuan memilih dan/atau penyebab-penyebab dan memprediksi kemungkinan akibat yang dapat terjadi; (3) Pembedaan (differentiating) yaitu kemampuan membedakan dan memilih penyebab-penyebab yang dapat menghasilkan suatu akibat tertentu; (4) Penentuan (determining) yaitu kemampuan menentukan konsep, prinsip, teori, dan/atau hukum fisika yang dapat digunakan untuk mendukung dalam mengidentifikasi sebuah atau beberapa penyebab sehingga menghasilkan suatu akibat; (5) Penerapan (applying) yaitu kemampuan menggunakan konsep, prinsip, teori, dan/atau hukum fisika dalam mengidentifikasi penyebabpenyebab sehingga menghasilkan suatu akibat tertentu; (6) Pengidentifikasian (identifying) yaitu kemampuan mengidentifikasi kondisi penyebabpenyebab sehingga dapat menghasilkan suatu akibat tertentu (Rokhmat, 2015). Instrumen tes kemampuan pemecahan masalah sebelum digunakan harus memenuhi beberapa syarat yaitu uji validitas, reliabilitas, tingkat kesukaran soal dan daya beda. Uji analisis data menggunakan uji-t polled varian dengan taraf signifikan $5 \%$ dan derajat kebebasan $\left(n_{1}+n_{2}\right)-2$. Data hasil kemampuan pemecahan masalah yang diperoleh dianalisis dengan $\mathrm{N}$-gain untuk mengetahui peningkatan kelas eksperimen dan kelas kontrol.

\section{HASIL DAN PEMBAHASAN}

Penelitian ini bertujuan untuk mengetahui apakah ada pengaruh model pembelajaran Conceptual Understanding Procedures berbantuan LKPD terhadap kemampuan pemecahan masalah fisika peserta didik pada SMA. Kemampuan yang diukur adalah kemampuan pemecahan masalah yang terdiri dari enam indikator. Tes kemampuan pemecahan masalah diberikan sebelum perlakuan dan sesudah perlakuan. Instrument menggunakan 7 soal kemampuan pemecahan masalah yang sudah divalidasi. Data tentang hasil kemampuan peserta didik sebelum dan sesudah perlakuan diperoleh melalui tes awal dan tes akhir.

Berdasarkan tes awal dan tes akhir terlihat bahwa adanya peningkatan kemampuan pemecahan masalah kedua kelas yang terlihat pada Tabel 1 .

Tabel 1. Perolehan Skor Rata-rata Kedua Kelas 


\begin{tabular}{lcc}
\hline \multicolumn{1}{c}{ Kelas } & Kemampuan & Rata-rata \\
\hline Eksperimen & Awal & 15,89 \\
& Akhir & 64,31 \\
Kontrol & Awal & 14,73 \\
& Akhir & 38,64 \\
\hline
\end{tabular}

Data pada Tabel 1 terlihat bahwa nilai ratarata kemampuan awal kelas eksperimen 15,89 sedangkan kelas kontrol 14,73. Sedangkan nilai rata-rata kemampuan akhir kelas eksperimen dan kelas kontrol berturut-turut 64,31 dan 38,64. Secara lebih terperinci terkait hubungan nilai antara tes awal dan tes akhir untuk data nilai tertinggi, terendah dan nilai rata-rata digambarkan dalam grafik berikut.

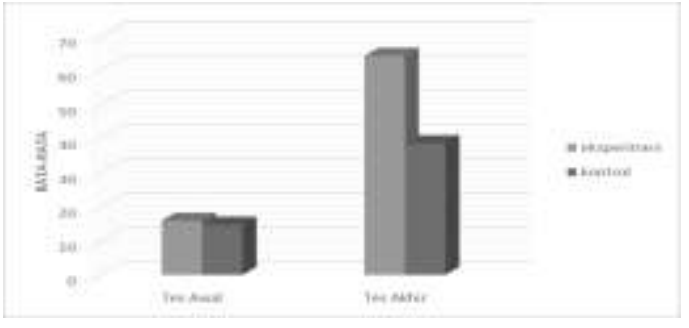

Grafik 1. Perbandingan Skor Rata-rata Kedua Kelas

Hasil tabulasi skor dan perhitungan tes awal dan tes akhir kemampuan pemecahan masalah peserta didik tiap-tiap IPM (Indikator Pemecahan Masalah), yang ditunjukkan Tabel 2 berikut.

Tabel 2. Persentase Nilai Rata-rata KPM Peserta Didik Kelas Eksperimen dan Kelas Kontrol

\begin{tabular}{cccccccc}
\hline Kelas & Kemampuan & IPM-1 & IPM-2 & IPM-3 & IPM-4 & IPM-5 & IPM-6 \\
\hline Eksperimen & \multirow{2}{*}{ Awal } & $38 \%$ & $19 \%$ & $7 \%$ & $8 \%$ & $10 \%$ & $15 \%$ \\
Kontrol & & $35 \%$ & $26 \%$ & $1 \%$ & $8 \%$ & $8 \%$ & $10 \%$ \\
Eksperimen & \multirow{2}{*}{ Akhir } & $87 \%$ & $60 \%$ & $49 \%$ & $50 \%$ & $69 \%$ & $70 \%$ \\
Kontrol & & $65 \%$ & $41 \%$ & $18 \%$ & $37 \%$ & $30 \%$ & $41 \%$ \\
\hline
\end{tabular}

Berdasarkan Tabel 2 diketahui bahwa persentase nilai rata-rata kemampuan pemecahan masalah peserta didik kelas eksperimen maupun kelas kontrol setiap indikator mengalami peningkatan setelah diberi perlakuan. IPM-1 mendapat persentase KPM dalam kategori rendah dengan nilai rata-rata $37 \%$ untuk kelas eksperimen dan 35\% kelas kontrol. Kemudian untuk IPM-2 mendapat persentase KPM dengan dalam kategori sangat rendah dengan nilai rata-rata 19\% untuk kelas eksperimen dan kategori rendah untuk kelas kontrol dengan nilai rata-rata 26\%, sedangkan untuk kedua kelas pada IPM-3 sampai dengan IPM-6 mendapat persentase KPM dalam kategori sangat rendah. Sedangkan setelah diberikan perlakuan hasil akhir kemampuan pemecahan masalah meningkat secara signifikan pada kelas eksperimen, dimana kemampuan pemecahan masalah peserta didik kelas eksperimen pada IPM-1 mendapat persentase KPM dalam kategori sangat tinggi dengan nilai rata-rata $87 \%$ kemudian untuk IPM-2, IPM-5, dan IPM-6 mendapat persentase tinggi dengan nilai rata-rata berturut-turut $60 \%$, 69\%, dan 70\%, untuk IPM-3 dan IPM-4 mendapat persentase KPM dalam kategori sedang dengan nilai rata-rata $49 \%$ dan $50 \%$. Sedangkan kemampuan pemecahan masalah peserta didik kelas kontrol pada IPM-1 mendapat persentase KPM dalam kategori tinggi dengan nilai rata-rata $65 \%$, untuk IPM-2 dan IPM-6 dalam kategori sedang dengan nilai rata-rata 41\%, kemudian untuk IPM-3, IPM-4, dan IPM-5 kategori rendah dengan nilai ratarata berturut-turut $18 \%, 27 \%$ dan 30\%. Dalam hal ini peningkatan kemampuan pemecahan masalah pada kelas eksperimen lebih tinggi dibandingkan dengan kelas kontrol.

Kemampuan pemecahan masalah yang lebih tinggi disebabkan pembelajaran berpusat pada peserta didik dan peserta didik diminta untuk mencari jawaban atas permasalahan tersebut sehingga peserta didik kemudian bereksplorasi lebih dalam untuk memecahkan permasalahan tersebut sehingga berakibat meningkatnya kemampuan pemecahan masalah peserta didik.

Pengujian data diawali dari pengujian homogenitas data dan normalitas data tes awal dan tes akhir menentukan jenis uji-t yang digunakan. Berdasarkan data tes awal yang diperoleh menunjukkan bahwa $F_{\text {hitung }}<F_{\text {tabel }}$ yaitu $1.41<1.78$, maka kedua sampel dikatakan homogen. Pada tes akhir juga terlihat bahwa 
$F_{\text {hitung }<} F_{\text {tabel }}$ yaitu $1.17<1.78, \quad$ sehingga kedua sampel dikatakan homogen. Hasil uji normalitas data juga menunjukkan bahwa data terdistribusi normal dimana untuk kelas eksperimen dan kelas kontrol nilai $\chi_{\text {hitung }}^{2}$ sebesar 8.494 dan 8,975 sedangkan nilai $\chi_{\text {tabel }}^{2}$ sebesar 12.592 dan 14.067. hasil tersebut menunjukkan bahwa $\chi_{\text {hitung }}^{2}<\chi_{\text {tabel }}^{2}$ yang berarti data terdistribusi normal. Uji prasyarat hipotesa telah dianalisis selanjutnya dilakukan uji hipotesis. Uji hipotesis yang digunakan adalah uji statistik parametrik yaitu uji-t polled varian. Hasil uji statistik (uji-t) menunjukkan nilai $t_{\text {hitung }}=7,091$.
Harga ini lebih besar dari harga $t_{\text {tabel }}=2,000$ pada taraf signifikan 5\%. Hal ini menunjukkan bahwa ada pengaruh model pembelajaran Conceptual Understanding Procedures (CUPs) berbantuan LKPD terhadap kemampuan pemecahan masalah fisika pada peserta didik SMA.

Untuk mengetahui kualitas peningkatan kemampuan pemecahan masalah peserta didik, dilakukan pengelompokan data peningkatan kemampuan pemecahan masalah peserta didik berdasarkan interpretasi gain ternormalisasi untuk masing-masing kelas. Komposisi interpretasi gain ternormalisasi disajikan dalam Tabel 2 berikut.

Tabel 2. Nilai N-gain Kemampuan Pemecahan Masalah Per Indikator

\begin{tabular}{|c|c|c|c|c|c|c|c|c|c|c|c|}
\hline \multirow[b]{2}{*}{ No. } & \multirow[b]{2}{*}{ Indikator } & \multicolumn{5}{|c|}{ Kelas Eksperimen } & \multicolumn{5}{|c|}{ Kelas Kontrol } \\
\hline & & $\mathrm{Jlh}$ & $\begin{array}{c}\text { Tes } \\
\text { Awal } \\
(\%)\end{array}$ & $\mathrm{Jlh}$ & $\begin{array}{c}\text { Tes } \\
\text { Akhir } \\
(\%)\end{array}$ & $\begin{array}{l}\mathrm{N}- \\
\text { gain } \\
(\%)\end{array}$ & $\mathrm{Jlh}$ & $\begin{array}{c}\text { Tes } \\
\text { Awal } \\
(\%)\end{array}$ & $\mathrm{Jlh}$ & $\begin{array}{c}\text { Tes } \\
\text { Akhir } \\
(\%)\end{array}$ & $\begin{array}{l}\mathrm{N}- \\
\text { gain } \\
(\%)\end{array}$ \\
\hline 1 & Memahami (IPM-1) & 92 & 38 & 214 & 87 & 79 & 82 & 35 & 151 & 65 & 44 \\
\hline 2 & Memilih (IPM-2) & 46 & 19 & 148 & 60 & 51 & 59 & 26 & 94 & 41 & 6 \\
\hline 3 & Membedakan (IPM-3) & 16 & 7 & 119 & 49 & 45 & 2 & 1 & 42 & 18 & 18 \\
\hline 4 & Menentukan (IPM-4) & 19 & 8 & 123 & 50 & 45 & 19 & 8 & 86 & 37 & 31 \\
\hline 5 & Menggunakan (IPM-5) & 24 & 10 & 170 & 69 & 66 & 19 & 8 & 69 & 30 & 24 \\
\hline 6 & Mengidentifikasi (IPM-6) & 36 & 15 & 172 & 70 & 65 & 23 & 10 & 94 & 41 & 34 \\
\hline & Rata-rata & & 16 & & 64 & 59 & & 15 & & 39 & 26 \\
\hline
\end{tabular}

Tabel 2 di atas menunjukkan peningkatan kemampuan pemecahan masalah peserta didik pada masing masing kelas setiap indikator, dan persentase rata-rata peningkatan kedua kelas. Persentase ratarata $\mathrm{N}$-gain pada kelas eksperimen lebih tinggi dari pada persentase rata-rata $\mathrm{N}$-gain pada kelas kontrol, dimana persentase rata-rata $\mathrm{N}$-gain pada kelas eksperimen sebesar 59\% dengan kategori sedang, dan pada kelas kontrol sebesar $26 \%$ dengan kategori rendah. Selisih persentase rata-rata N-gain kelas eksperimen dan kelas kontrol adalah sebesar 33\%. Kemampuan pemecahan masalah kelas eksperimen yang lebih tinggi disebabkan pembelajaran berpusat pada peserta didik dan peserta didik diminta untuk mencari jawaban atas permasalahan tersebut sehingga peserta didik kemudian bereksplorasi lebih dalam untuk memecahkan permasalahan tersebut sehingga membuat pemahaman peserta didik lebih bermakna dan berakibat meningkatnya kemampuan pemecahan masalah peserta didik.

Perhitungan rata-rata N-gain juga dilakukan untuk mengetahui peningkatan kemampuan pemecahan masalah peserta didik per indikator. Indikator pemecahan masalah pada penelitian ini terdiri atas enam indikator, yaitu (1) memahami, (2) memilih, (3) membedakan, (4) menerapkan, (5) menggunakan, dan (6) mengidentifikasi. Hasil perhitungan persentase $\mathrm{N}$-gain per indikator pada kedua kelas ditunjukkan pada Grafik 2 berikut. 


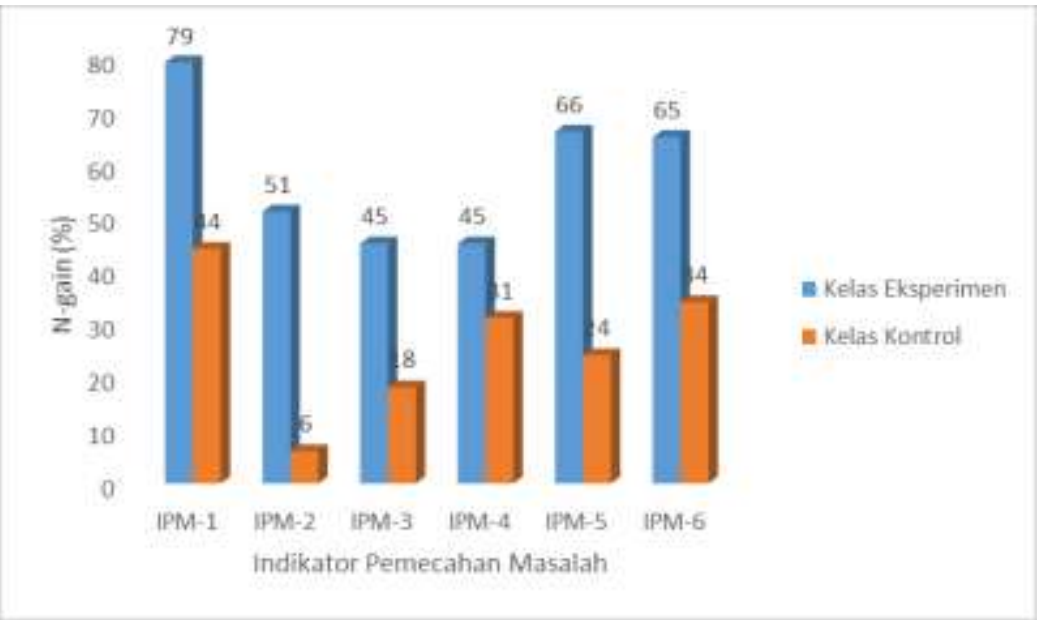

Grafik 2. Persentase Peningkatan Kemampuan Pemecahan Masalah Peserta Didik pada Kedua Kelas

Grafik di atas menunjukkan bahwa pada indikator pemecahan masalah 1 (IPM-1), kelas eksperimen mengalami peningkatan kemampuan pemecahan masalah yang lebih tinggi dibandingkan dengan kelas kontrol, dimana peningkatan pada kelas ekperimen sebesar $79 \%$ dan peningkatan pada kelas kontrol sebesar 44\%. Perbedaan yang lain juga terjadi pada IPM-2, IPM-3, IPM-4, IPM-5, dan IPM6 , dimana kelas eksperimen mengalami peningkatan yang lebih tinggi daripada kelas kontrol. Peningkatan paling rendah untuk kelas eksperimen ada pada indikator kemampuan membedakan dan menentukan. Sedangkan pada kelas kontrol ada pada indikator memilih.

Hasil penelitian yang sudah dilakukan menggambarkan bahwa kemampuan pemecahan masalah peserta didik berbeda. Kelas eksperimen maupun kelas kontrol mengalami peningkatan, namun peningkatan kelas eksperimen lebih baik daripada peningkatan pada kelas kontrol. Hal ini disebabkan karena peneliti menerapkan model pembelajaran CUPs berbantuan LKPD pada kelas eksperimen. Dalam pembelajaran CUPs terdapat tiga fase pembelajaran yang dilaksanakan oleh peserta didik pada kelas eksperimen. Menurut Saregar, Latifah \& Sari (2016) menyatakan bahwa tiga fase model Conceptual understanding Procedures dibangun atas tiga fase, yaitu (1) fase individu, (2) fase kerja kelompok, dan (3) fase presentase. Pada fase kerja individu peserta didik mengerjakan lembar kerja individu berupa suatu permasalahan pada materi fisika yang kemudian didiskusikan kembali pada fase kerja kelompok. Hal tersebut dilakukan agar peserta didik mampu menemukan sendiri jawaban permasalahan dengan melalui kerja kelompok maupun diskusi kelas berdasarkan keberagaman jawaban yang mereka miliki.

Temuan dalam penelitian ini memperkuat beberapa penelitian sebelumnya diantaranya adalah penelitian yang dilakukan Siswanto et al, (2013) menyatakan bahwa implementasi model Conceptual Understanding Procedures dapat meningkatkan kemampuan kognitif $\mathrm{C} 2$ peserta didik yang berpengaruh besar terhadap peningkatan hasil belajar peserta didik. Penelitian Hidayati \& Sinulingga, (2015) menyatakan bahwa ada perbedaaan siginifikan akibat pengaruh model pembelajaran Conceptual Understanding Procedures (CUPs) terhadap hasil berlajar siswa pada materi pokok listrik dinamis di kelas X. Penelitian Gummah et al, (2014) menyatakan bahwa melalui penerapan model pembelajaran kooperatif teknik Conceptual Understanding Procedures (CUPs) dapat meningkatkan hasil belajar dan aktivitas siswa kelas VIII SMP Negeri 13 Mataram. Penelitian Saregar et al (2016) menyatakan bahwa terdapat perbedaan rerata kemampuan berpikir tingkat tinggi peserta didik antara menggunakan model Conceptual Understanding Procedures dengan menggunakan model konvensional. Penelitian Prastiwi et al, (2014) juga menyatakan bahwa penerapan pembelajaran Conceptual Understanding Procedures efektif terhadap kemampuan koneksi matematika siswa. Hasil penelitian ini membuktikan penggunaan model 
pembelajaran Conceptual Understanding Procedures (CUPs) berbantuan LKPD dalam pembelajaran berpengaruh positif terhadap kemampuan pemecahan masalah fisika peserta didik. Untuk mengetahui model pembelajaran conceptual understanding procedures (CUPs) berbantuan LKPD berpengaruh positif terhadap peningkatan kemampuan pemecahan masalah fisika peserta didik dilakukan uji hipotesis berdasarkan skor $\mathrm{N}$-gain. Berdasarkan hasil uji hipotesis untuk skor $\mathrm{N}$-gain didapatkan nilai $t_{\text {hitung }}=7,489$. Nilai $t_{\text {hitung }}$ ini lebih besar dari pada nilai $t_{\text {tabel }}$. Hal ini berarti bahwa model pembelajaran conceptual understanding procedures (CUPs) berbantuan LKPD berpengaruh terhadap kemampuan pemecahan masalah fisika peserta didik dimana model tersebut menyebabkan peningkatan kemampuan pemecahan masalah fisika peserta didik yang yang positif.

\section{KESIMPULAN}

Berdasarkan hasil penelitian dan pembahasan, dapat disimpulkan bahwa ada pengaruh model pembelajaran Conceptual Understanding Procedures (CUPs) berbantuan LKPD terdapat kemampuan pemecahan masalah fisika SMA. Kelas eksperimen dan kelas kontrol mengalami peningkatan pada setiap indikator. Peningkatan kemampuan pemecahan masalah peserta didik kelas eksperimen lebih tinggi dibandingkan kelas kontrol. Hasil N-gain menyatakan bahwa peningkatan tertinggi pada kedua kelas terjadi pada indikator pemecahan masalah 1 yaitu memahami, sedangkan peningkatan terendah terjadi pada indikator pemecahan masalah membedakan dan menentukan untuk kelas eksperimen dan peningkatan terendah terjadi pada indikator pemecahan masalah memilih untuk kelas kontrol. Karena kemampuan pemecahan masalah fisika peserta didik kelas eksperimen lebih tinggi dari kelas kontrol, hal ini berarti bahwa penerapan model pembelajaran Conceptual Understanding Procedures (CUPs) berbantuan LKPD berpengaruh positif terhadap kemampuan pemecahan masalah fisika peserta didik SMA.

\section{DAFTAR PUSTAKA}

Anggreni, K. R., Meter, I. G., \& Wiarta, I. W. (2013). Model Pembelajaran Conceptual
Understanding Procedures Berpengaruh Terhadap Hasil Belajar Matematika Siswa Kelas V SD Gugus VII Kompiang Sujana Denpasar Barat. Mimbar Pgsd, 1, 12-21.

Damayanti, D. S. (2013). Pengembangan Lembar Kerja Siswa (LKS) Dengan Pendekatan Inkuiri Terbimbing Untuk Mengoptimalkan Kemampuan Berpikir Kritis Peserta Didik Pada Materi Listrik Dinamis SMA Negeri 3 Purworejo Kelas X Tahun Pelajaran 2012/2013. RADIASI: Jurnal Berkala Pendidikan Fisika, 3(1), 58-62.

Dwi, I. M., Arif, H., \& Sentot, K. (2013). Pengaruh Strategi Problem Based Learning Berbasis ICT Terhadap Pemahaman Konsep dan Kemampuan Pemecahan Masalah Fisika. Jurnal Pendidikan Fisika Indonesia, 9(1), 8-17.

Fransiska, Y., \& Markos, S. (2016). Pengembangan Lembar Kerja Siswa Berbasis Kecerdasan Majemuk Untuk Pembelajaran Fisika Sma Kelas X Pada Materi Elastisitas. Jurnal Inovasi Dan Pembelajaran Fisika, 3(1), 7379.

Gummah, S., Soraya, L. H., Ahzan, S., \& Hardariyanti, H. (2014). Penerapan Model Pembelajaran Kooperatif Teknik Conceptual Understanding Procedures Untuk Meningkatkan Hasil Belajar Dan Aktivitas Siswa. Prisma Sains: Jurnal Pengkajian Ilmu dan Pembelajaran Matematika dan IPA IKIP Mataram, 2(2), 310-315.

Gunawan, G., Harjono, A., \& Sutrio, S. (2015). Multimedia Interaktif dalam Pembelajaran Konsep Listrik bagi Calon Guru. Jurnal Pendidikan Fisika dan Teknologi, 1(1), 9-14.

Gunawan, G., Harjono, A., \& Sahidu, H. (2015). Studi Pendahuluan Pada Upaya Pengembangan Laboratorium Virtual bagi Calon Guru Fisika. Jurnal Pendidikan Fisika dan Teknologi, 1(2), 140-145.

Hariawan, H., Kamaluddin, K., \& Wahyono, U. (2014). Pengaruh model pembelajaran creative problem solving terhadap kemampuan memecahkan masalah fisika pada siswa kelas XI SMA Negeri 4 Palu. Ejurnal Pendidikan Fisika Tadulako, 1(2), 48-54.

Hastuti, A., Sahidu, H., \& Gunawan, G. (2016). Pengaruh Model PBL Berbantuan Media Virtual Tehadap Kemampuan Pemecahan 
Masalah Fisika. Jurnal Pendidikan Fisika dan Teknologi, 2(3), 129-135.

Hermansyah, H., Gunawan, G., \& Herayanti, L. (2015). Pengaruh Penggunaan Laboratorium Virtual Terhadap Penguasaan Konsep dan Kemampuan Berpikir Kreatif Siswa pada Materi Getaran dan Gelombang. Jurnal Pendidikan Fisika dan Teknologi, 1(2), 97 102.

Hertiavi, M. A., Langlang, H., \& Khanafiyah, S. (2010). Penerapan model pembelajaran kooperatif tipe jigsaw untuk peningkatan kemampuan pemecahan masalah siswa SMP. Jurnal Pendidikan Fisika Indonesia, 6(1), 53-57.

Hidayati, F., \& Sinulingga, K. (2015). Pengaruh Model Pembelajaran Conceptual Understanding Procedures (Cups) Terhadap Hasil Belajar Siswa Pada Materi Pokok Listrik Dinamis Di Kelas X Semester II SMA Negeri 1 Binjai TP 2014/2015. INPAFI (Inovasi Pembelajaran Fisika), 3(4), 59-66.

Hikmah, N., Baidowi, B., \& Kurniati, N. (2014). Penerapan Model Pembelajaran Conceptual Understanding Procedures (CUPs) untuk Meningkatkan Aktivitas dan Hasil Belajar Matematika Siswa Kelas X SMA Negeri 7 Mataram. Jurnal Pijar MIPA. 9(2), 84-88.

Husna, M., \& Fatimah, S. (2013). Peningkatan kemampuan pemecahan masalah dan Komunikasi matematis siswa Sekolah Menengah Pertama melalui model pembelajaran kooperatif tipe Think-pair-share (TPS). Jurnal Peluang, 1(2), 81-92.

Ismawati, F., Nugroho, S. E., \& Dwijananti, P. (2014). Penerapan Model Pembelajaran Conceptual Understanding Procedures (Cups) untuk Meningkatkan Pemahaman Konsep dan Curiosity Siswa pada Pelajaran Fisika. Jurnal Pendidikan Fisika Indonesia. 10(1), 22-27.

Lubis, R. R., \& Lestari, R. (2017). Pengembangan Lembar Kerja Siswa Berbasis Inkuiri Untuk Kelas Viii Smp Negeri 5 Rambah Samo Pada Materi Gerak Pada Tumbuhan. Jurnal Ilmiah Mahasiswa FKIP Prodi Biologi, 3(1).

Prastiwi, I., Soedjoko, E., \& Mulyono, M. (2014). Efektivitas Pembelajaran Conceptual Understanding Procedures Untuk Meningkatkan Kemampuan Siswa Pada Aspek Koneksi Matematika. Jurnal Kreano. 5(1): 41-47.
Prastowo, A. 2015. Panduan Kreatif Membuat Bahan Ajar Inovatif. Jogjakarta: DIVA Press.

Rahmat, M., Muhardjito, M., \& Zulaikah, S. (2014). Kemampuan Pemecahan Masalah Melalui Strategi Pembelajaran Thinking Aloud Pair Problem Solving Siswa Kelas X SMA. Jurnal Fisika Indonesia. 18(54), 108-112.

Rokhmat, J. 2015. Penerapan Pendekatan Berpikir Kausalitik Ber-scaffolding dalam Meningkatkan KPM Hukum Newton tentang Gerak. Prosiding Seminar Nasional Fisika.

Sagala, S. 2013. Konsep dan Makna Pembelajaran. Bandung: Alfabeta.

Sahidu, C. 2013. Pengembangan Program Pembelajaran Fisika (P3F). Mataram: FKIP Press.

Sambada, D. (2012). Peranan Kreativitas Siswa Terhadap Kemampuan Memecahkan Masalah Fisika dalam Pembelajaran Kontekstual. Jurnal Penelitian Fisika dan Aplikasinya, 2(2), 37-42.

Santrock, J. W. 2011. Educational Psychology Fifth Edition. New York: McGraw-Hill.

Saregar, A., Latifah, S., \& Sari, M. (2016). The Effectiveness of Model Learning CUPs: Impact on The Higher Order Thinking Skill Students at Madrasah Aliyah Mathla'ul Anwar Gisting Lampung. Jurnal Ilmiah Pendidikan Fisika Al-BiRuNi, 5(2), 235-246.

Sinambela, K. N., \& Turnip, B. M. (2015). Pengaruh Model Pembelajaran Berbasis Masalah Terhadap Hasil Belajar Siswa Pada Materi Gerak Lurus di Kelas X SMA Negeri 5 Medan TP 2014/2015. INPAFI (Inovasi Pembelajaran Fisika), 3(3), 95-103.

Siswanto, B., Sriyono, dan Maftukhin, A. 2013. Implementasi Model Conceptual Understanding Procedures (CUPs) dalam Pembelajaran Fisika untuk Meningkatkan Kemampuan Kognitif C2 Siswa Kelas X SMK YPT Purworejo. Radiasi. 4(1), 38.

Sugiana, I. N., Harjono, A., Sahidu, H., \& Gunawan, G. (2016). Pengaruh Model Pembelajaran Generatif Berbantuan Media Laboratorium Virtual Terhadap Penguasaan Konsep Fisika Siswa pada Materi Momentum dan Impuls. Jurnal Pendidikan Fisika dan Teknologi, 2(2), 61-65. 
Sugiyono. 2012. Statistika Untuk Penelitian. Suranti, N. M. Y., Gunawan, G., \& Sahidu, H. Bandung: Alfabeta. (2016). Pengaruh Model Project Based Learning Berbantuan Media Virtual Terhadap Penguasaan Konsep Peserta didik pada Materi

Sukmawati, N. A., \& Lestari, R. (2017). Pengembangan Lembar Kerja Siswa Berbasis Inkuiri Terbimbing Untuk Kelas VII SMP Muhammadiyah Rambah Pada Materi Pencemaran Dan Kerusakan Lingkungan. Jurnal Ilmiah Mahasiswa FKIP Prodi Biologi, 3(1).

Sulistyowati, N., Widodo, A. T. W. T., \& Sumarni, W. (2012). Efektivitas Model Pembelajaran Guided Discovery Learning Terhadap Kemampuan Pemecahan Masalah Alat-alat Optik. Jurnal Pendidikan Fisika dan Teknologi, 2(2), 73-79.

Trianto. 2010. Model Pembelajaran Terpadu. Jakarta: Bumi Aksara.

Venisari, R., Gunawan, G., \& Sutrio, S. (2015). Penerapan Metode Mind Mapping pada Model Direct Instruction untuk Meningkatkan Kemampuan Pemecahan Masalah Fisika Siswa SMPN 16 Mataram. Jurnal Pendidikan Kimia. Chemistry in Education, 1(2), 49-55. Fisika dan Teknologi, 1(3), 193-199. 